\title{
DINAMIKA DAERAH PENANGKAPAN TUNA MADIDIHANG (Thunnus albacares) DI PERAIRAN LAUT BANDA
}

\section{DYNAMICS FISHING GROUND YELLOWFIN TUNA, Thunnus albacares IN BANDA SEA WATERS}

\author{
Haruna $^{1}$, J.B Paillin ${ }^{1}$, Ruslan.H.S. Tawari ${ }^{1}$, A Tupamahu ${ }^{1}$, S.R. Siahainenia ${ }^{1}$, F.D. Silooy ${ }^{1}$ \\ ${ }^{1}$ Fakultas Perikanan dan Ilmu Kelautan Universitas Pattimura Ambon \\ Jl. Mr. Chr. Soplanit Kampus Poka-Ambon \\ email: haruna.unpatti@gmail.com
}

\begin{abstract}
ABSTRAK
Tujuan penelitian mengetahui produksi, musim penangkapan dan hubungan parameter oseanografi dengan hasil tangkapan tuna madidihang di Perairan Laut Banda. Parameter oseanografi difokuskan pada sebaran suhu permukaan laut dan konsentrasi klorofil-a. Pengambilan data dimulai pada bulan Juli 2016 sampai Juni 2017. Studi ini menggunakan dua jenis data yaitu data primer mencakup jenis dan jumlah hasil tangkapan serta posisi penangkapan ikan, data sekunder mencakup data citra satelit oseanografi yang bersumber dari satelit MODIS. Data yang diperoleh dianalisis dengan menggunakan presentase rata-rata dan Generalized Additive Models (GAMs). Kontribusi produksi tuna madidihang (Thunnus albacares) sebesar $14.539,5$ ton $(59,9 \%)$, tuna mata besar (Thunnus obesus) sebesar $6.242,1$ ton $(25,7 \%)$, dan tuna tongkol abu-abu (Thunnus tonggol) sebesar $3.477,6$ ton $(14,3 \%)$. CPUE rata-rata armada pancing ulur $1.011,73 \mathrm{~kg} / \mathrm{bulan}$, dan periode musim penangkapan ikan bulan Januari-April dan Oktober-Desember. Terdapat Hubungan signifikan antara dinamika kondisi oseanografi (Suhu Permukaan Laut dan konsentarsi klorofil-a) dengan hasil tangkapan tuna madidihang di perairan Laut Banda. Kondisi optimal parameter Suhu Permukaan Laut berkisar antara $30^{\circ} \mathrm{C}-30,5^{\circ} \mathrm{C}$ dengan konsentrasi klorofil-a $0,1-0,2 \mathrm{mg} / \mathrm{m}^{3}$.
\end{abstract}

KATA KUNCI : Tuna Madidihang, Kondisi Oseanografi, Fishing Ground, Laut Banda

\begin{abstract}
The purpose of the study was to determine the production, catch season and the relationship of oceanographic parameters with the catch of yellowfin tuna in the Banda Sea waters. Oceanographic parameters are focused on the distribution of sea surface temperature and chlorophyll-a concentration. Data collection began in July 2016 to June 2017. This study uses two types of data, namely primary data including the type and number of catches and fishing positions, secondary data includes oceanographic satellite imagery data sourced from MODIS satellites. The data obtained were analyzed using mean percentages and Generalized Additive Models (GAMs). Contribution of production Thunnus albacares was 14,539.5 tons (59.9\%), Thunnus obesus was 6,242.1 tons (25.7\%), and Thunnus tonggol was 3,477,6 tons (14.3\%). The average CPUE of the fishing line fleet is $1,011.73 \mathrm{~kg} /$ month, and the fishing season period is January-April and OctoberDecember. There is a significant relationship between the dynamics of oceanographic conditions (Sea Surface Temperature and chlorophyll-a concentration) and the catch of yellowfin tuna in the Banda Sea waters. Optimal conditions of Sea Surface Temperature parameters range between $30^{\circ}$ C-30.5 ${ }^{\circ} \mathrm{C}$ with a chlorophyll-a concentration of $0.1-0.2 \mathrm{mg} / \mathrm{m}^{3}$.
\end{abstract}

KEYWORDS: Yellowfin tuna, Oceanographic Condition, Fishing Ground, Banda Sea 


\section{PENDAHULUAN}

Laut Banda memiliki potensi keanekaragaman hayati laut merupakan wilayah lintasan migrasi ikan pelagis besar dan termasuk dalam wilayah "Coral Triangle Tuna" sebagai habitat utama breeding ground dan nursery ground (Cabral et al, 2012; Bailey et $a l, 2012$ ). Secara nasional sumberdaya tuna diantaranya jenis madidihang (Thunnus albacares) telah memberikan kontribusi produksi maupun nilai ekonomis penting di wilayah pemanfaatan Laut Banda.

Distribusi keberadaan ikan tuna pada Wilayah Zona Ekonomi Eksklusif (ZEE) Indonesia sebagai bagian dari jalur migrasi tuna dunia dan lintasan perbatasan perairan antara Samudra Hindia dan Samudra Pasifik. Migrasi kelompok tuna yang melintasi wilayah perairan pantai dan teritorial berhubungan langsung dengan pengaruh kondisi hidro-oseanografi dan pola migrasi (Simbolon, 2011). Daerah Penangkapan ikan tuna sangat tergantung pada faktor-faktor lingkungan seperti suhu permukaan laut, salinitas, klorofil-a, perbedaan kecepatan arus, kedalaman, front dan upwelling (Zainuddin et al, 2013; Jufri dkk, 2014) serta kelimpahan ikan. Kelimpahannya ditentukan oleh kondisi optimal perairan yang mendukung bagi kehidupannya.

Dinamika kondisi lingkungan mengindikasikan pola sebaran sumberdaya ikan tidak merata, adanya pergeseran musim, ketidakpastian lokasi keberadaan ikan dan daerah penangkapan sehingga mempengaruhi produksi dan produktivitas hasil tangkapan (Haruna et al, 2018; Tawari et al, 2019,). Oleh karena itu, optimalisasi pemanfaatan ikan tuna madidihang di perairan Laut Banda membutuhkan informasi dasar yang memadai tentang daerah potensial penangkapan ikan dengan mengkombinasikan data survei lapangan dan data citra satelit. Data citra satelit sangat bermanfaat khususnya untuk mengkaji daerah potensial penangkapan ikan pada wilayah yang luas dan cepat (Safruddin et al, 2018).

Penelitian ini bertujuan: (1) mendeskripsikan produksi dan pola musim penangkapan tuna madidihang di wilayah perairan Laut Banda, (2) menganalisis hubungan parameter oseanografi dengan hasil tangkapan tuna madidihang di Perairan Laut Banda. Informasi ini penting untuk meningkatkan efisiensi dan efektifitas operasi penangkapan ikan.

\section{METODE PENELITIAN}

\section{Waktu dan Tempat}

Penelitian dilaksanakan pada bulan Juli 2016 sampai Juni 2017 di Perairan bagian selatan Pulau Seram, Laut Banda. Fishing base nelayan pancing ulur tuna madidihang berada di 2 Kecamatan yaitu Amahai dan Tehoru, Kabupaten Maluku Tengah. Peta daerah operasi penangkapan tuna madidihang diperlihatkan pada Gambar 1.

\section{Metode Pengumpulan Data}

Pengumpulan data primer meliputi: pencatatan data jumlah hasil tangkapan dan upaya penangkapan masing-masing unit armada tangkap per bulan selama tahun 20152017 dan titik koordinat operasi penangkapan ikan menggunakan Global Positioning System (GPS) dari nelayan sampel dengan bantuan enumerator pada setiap lokasi fishing base sebanyak 1.948 spot dari bulan Juli 2016 sampai Juni 2017. Data sekunder meliputi: data time series produksi perikanan tuna di Maluku dan data citra satelit oseanografi (suhu permukaan laut dan konsentrasi klorofil-a) bersumber dari satelit MODIS (http://oceancolor.gsfc.nasa.gov/) dengan resolusi masing-masing sebesar $4 \mathrm{~km}$ dan dilengkapi software pengolah data spasial yaitu SeaWiFS Data Analysis System (SEADAS), ArcGIS 10.2, dan R Program 3.4.3. 


\section{Analisis Data}

Analisis dinamika musim penangkapan menggunakan metode presentase rata-rata (The Average Percentage Methods) menurut runtun waktu dalam periode pengamatan (Kakenusa, 2006). Hubungan hasil tangkapan ikan dan dinamika parameter oseanografi (suhu permukaan laut, dan densitas klorofil-a) dengan menggunakan model statitstik Generalized Additive Model (GAM) (Safruddin et al, 2018; Zainuddin et al, 2019) dengan formula sebagai berikut:

$$
\begin{gathered}
\text { CPUE }=\alpha_{0}+s 1(\text { SPL })+s 2(\text { klorofil-a })+\varepsilon \\
g(\mu \mathrm{ij})=\frac{\sum \text { Lij (CPUE)ij }}{\sum C P U E i j}
\end{gathered}
$$

dimana $\alpha_{0}=$ konstanta; $s_{\mathrm{n}}=$ smoothing function; $\beta \mathrm{n}$ (parameter oseanografi) $=$ variabel bebas; $\varepsilon=$ : standar error; $g \mu \mathrm{ij}=$ pusat gravitasi bulanan tempat penangkapan ikan di posisi bujur dan lintang pada posisi Lij; CPUE = upaya penangkapan per unit (hasil tangkapan ikan /set)

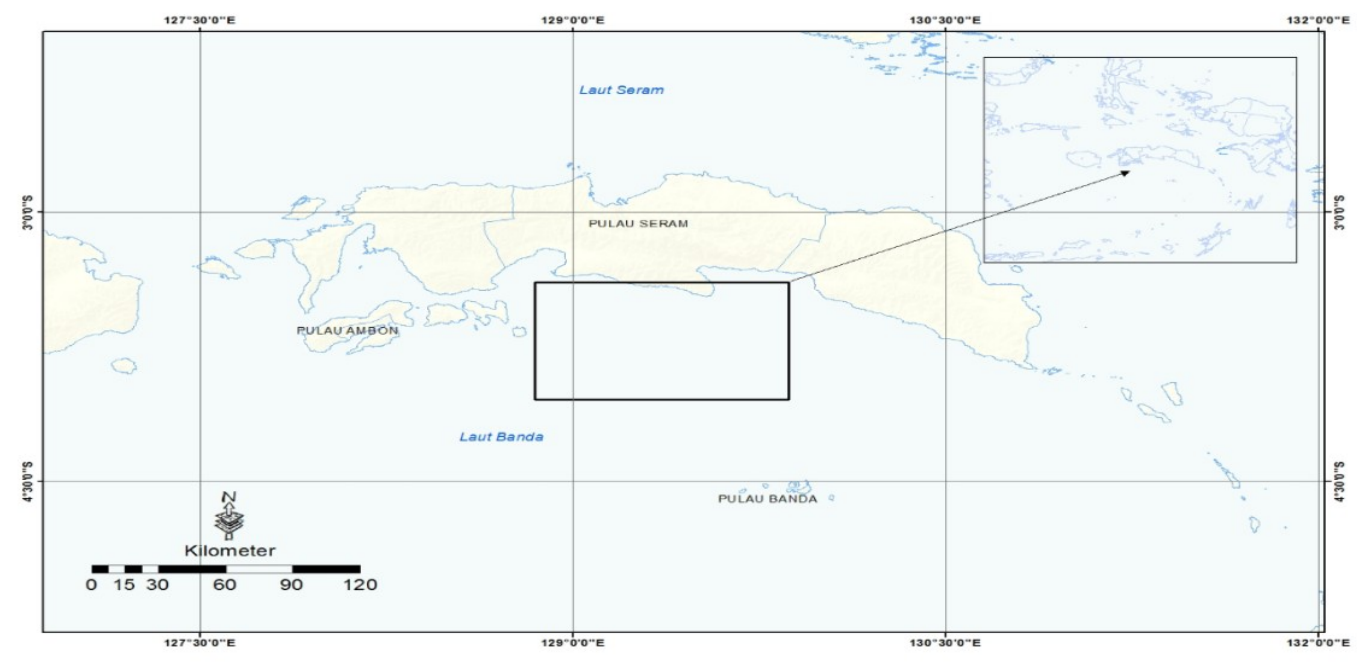

Gambar 1. Peta Daerah Operasi Penangkapan Tuna Madidihang Di Laut Banda

\section{HASIL DAN PEMBAHASAN}

\section{Produksi, CPUE, dan Musim Penangkapan}

Produksi perikanan komoditas utama tuna (non cakalang) tahun 2012-2016 terdapat tiga jenis. Pada Ganbar 2 menunjukkan bahwa kontribusi jenis madidihang (Thunnus albacares) sebesar 14.539,5 ton (59,96\%), tuna mata besar (Thunnus obesus) sebesar 6.242,1 ton (25,73\%), dan tongkol abu-abu (Thunnus tonggol) sebesar 3.477,6 ton (14,31\%). Hubungan hasil tangkapan per upaya tangkap (CPUE) bulanan armada pancing ulur tuna madidihang tahun 2015-2017 cenderung berfluktuatif dengan pola yang hampir cenderung sama. CPUE rata-rata bulanan sebesar $1.011,73 \mathrm{~kg} / \mathrm{unit}$, tertinggi terjadi pada bulan Nopember dengan nilai sebesar $2,014 \mathrm{~kg} / \mathrm{unit}$ dan nilai CPUE terendah pada bulan Agustus sebesar $270 \mathrm{~kg} / \mathrm{unit}$ (Gambar 3).

Pendugaan indeks musim penangkapan perbulan dengan metode persentase rata-rata menunjukkan bulan Januari-April dan Oktober-Desember sebagai musim tangkap dengan nilai indeks yang lebih dari 100\%, puncak musim pada bulan Nopember 
(Gambar 4). Kategori Musim Paceklik terjadi pada Musim Timur dan awal musim Peralihan II tepatnya di bulan Juli, Agustus, September akibat dari terjadi musim angin timur yang cenderung berombak besar sehingga jumlah trip penangkapan berkurang.

$\square$ Madidihang (Thunnus albacares)

$\square$ Mata Besar (Thunnus obesus)

$\square$ Tongkol Abu-Abu (Thunnus tonggol)

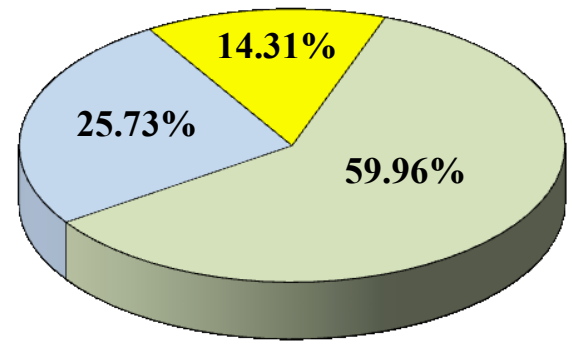

Gambar 2.Kontribusi Produksi Komoditas Tuna Di Maluku

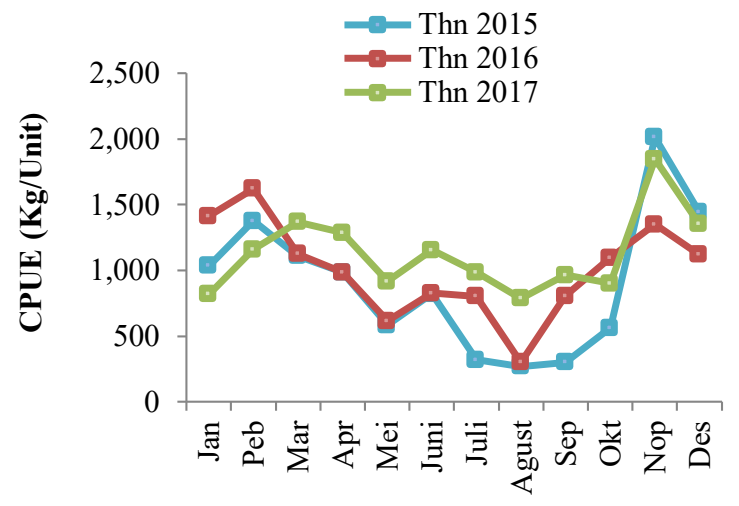

Gambar 3. CPUE bulanan armada pencing ulur Tuna Madidihang

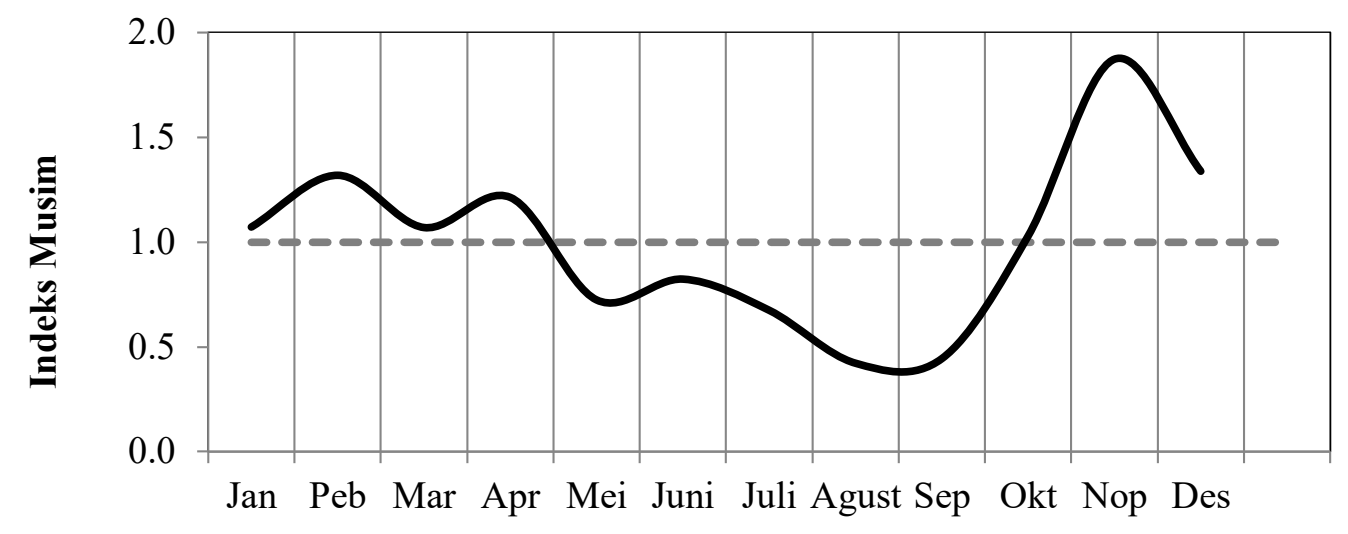

Gambar 4. Indeks Musim Penangkapan Tuna Madidihang di Laut Banda

Dinamika perubahan musim memaksa nelayan mengoptimalkan operasi penangkapan secara terencana, efisien dan intensif pada bulan-bulan musim tangkap di wilayah sekitar areal rumpon. Musim penangkapan di sekitar Perairan Pelabuhan Ratu Mei-Oktober, puncak musim bulan Juni (Nurdin dkk, 2015), di Laut Flores puncak musim Oktober-Desember (Zainuddin dkk, 2015), di Laut Maluku dan Laut Sulawesi musim penangkapan Januari, Juli, Agustus, September, Oktober dan Nopember (Setiawan dkk, 2016).

\section{Distribusi Suhu Permukaan Laut}

Distribusi Suhu Permukaan Laut pada daerah penangkapan berkisar antara $27.11^{\circ} \mathrm{C}-31.43^{\circ} \mathrm{C}$ dengan suhu terendah bulan Juli yaitu $26,63^{\circ} \mathrm{C}-27,78^{\circ} \mathrm{C}( \pm 0,26)$ dan tertinggi bulan Desember yaitu $30,79^{\circ} \mathrm{C}-31,98^{\circ} \mathrm{C}( \pm 0,28)$. Pola distribusi suhu permukaan mengikuti trend kenaikan dari suhu dingin ke suhu lebih hangat bulan Juli-Nopember, suhu permukaan cenderung stabil, walaupun sedikit mengalami penurunan bulan Desember-Juni (Gambar 5). Pada Gambar 6 menunjukkan bahwa distribusi koordinat penangkapan di areal fishing ground pada kisaran suhu $29,5^{\circ} \mathrm{C}-32,0^{\circ} \mathrm{C}$, tangkapan tertinggi pada suhu $31,5^{\circ} \mathrm{C}$ sebesar $25,69 \%$. Distribusi spasial spot lokasi penangkapan setiap bulan mengalami pergeseran, musim peralihan II (September-Nopember) 
dan musim barat (Desember-Pebruari) berada pada kondisi suhu hangat, gelombang dan arus sangat mendukung kapal melakukan proses penangkapan ikan jauh dari daerah pantai (Gambar 7).

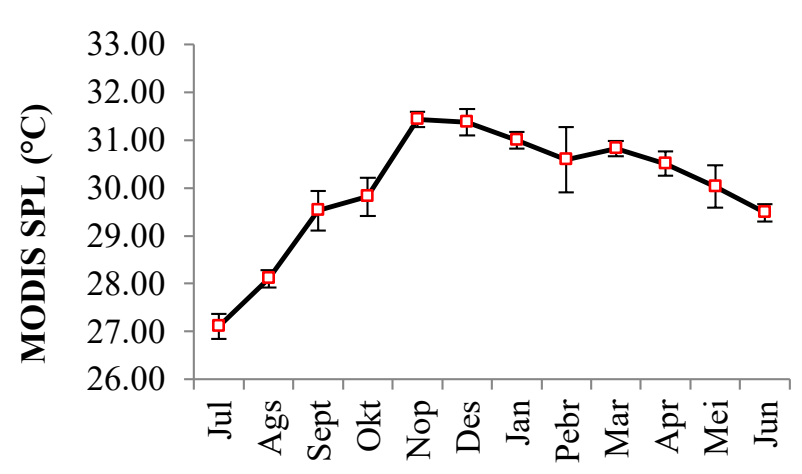

Gambar 5. Rata-rata SPL Pada Areal penangkapan Laut Banda

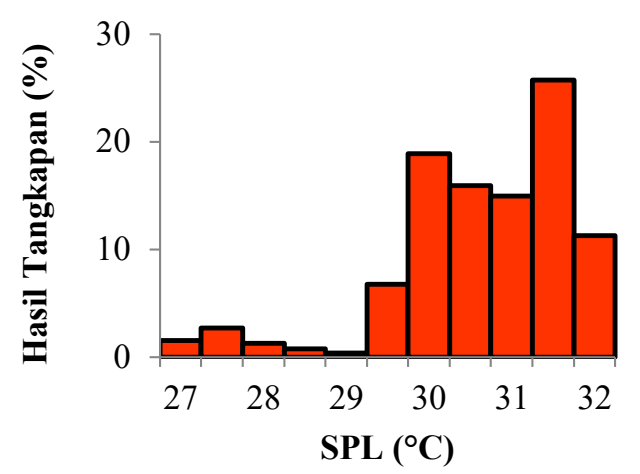

Gambar 6. Presentase Hasil Tangkapan Pada SPL Areal Penangkapan Laut Banda

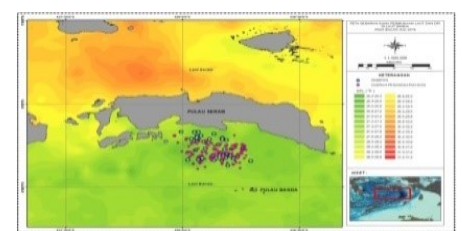

Juli

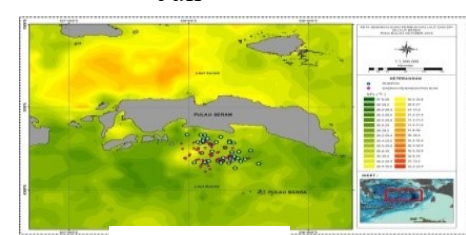

Oktober

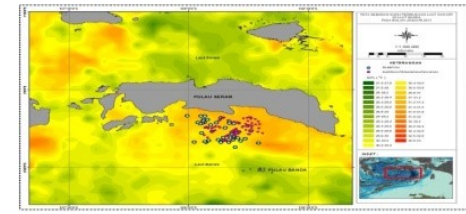

Januari

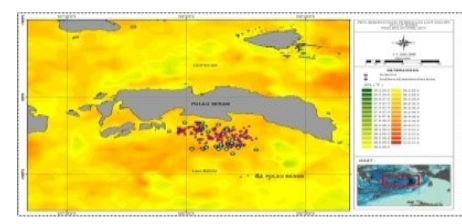

April

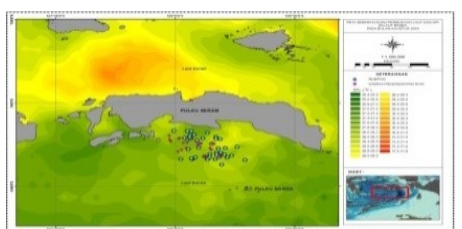

Agustus

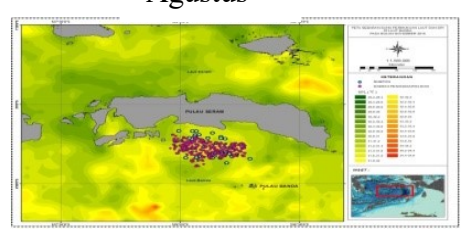

Nopember

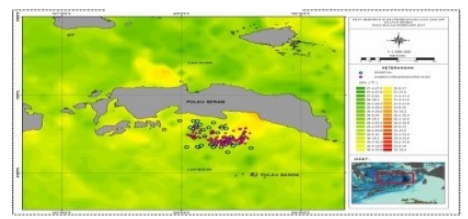

Pebruari

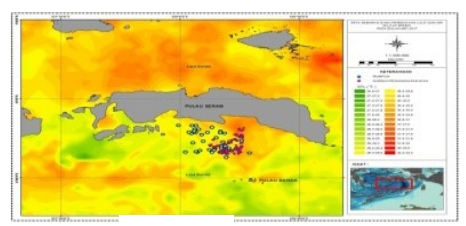

Mei

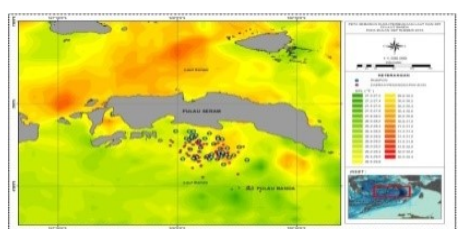

September

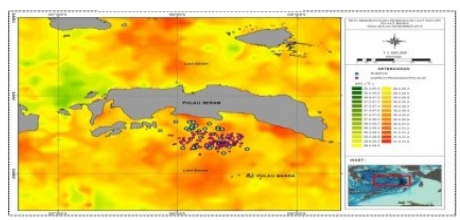

Desember

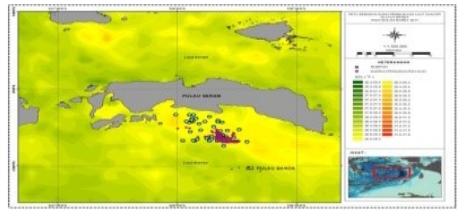

Maret

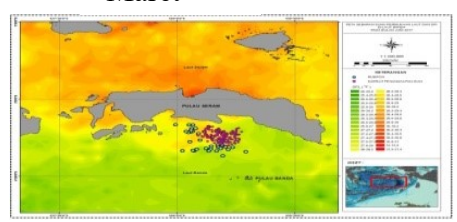

Juni

Gambar 7. Peta Distribusi Daerah Penangkapan Ikan Tuna Madidihang hubungan dengan SPL Di Laut Banda

\section{Distribusi Klorofil-a}

Distribusi klorofil-a pada daerah penangkapan Laut Banda berkisar antara 0,099 $\mathrm{mg} / \mathrm{m}^{3}-0,372 \mathrm{mg} / \mathrm{m}^{3}$, mengalami peningkatan bulan Juli dengan variasi yang tinggi yaitu $0,221 \mathrm{mg} / \mathrm{m}^{3}-0,797 \mathrm{mg} / \mathrm{m}^{3}( \pm 0,137)$ dan menurun bulan Desember yaitu $0,087 \mathrm{mg} / \mathrm{m}^{3}-$ $0,138 \mathrm{mg} / \mathrm{m}^{3}( \pm 0,007)$ dapat dilihat pada Gambar 8. Peningkatan jumlah hasil tangkapan 
pada densitas klorofil-a $0,2 \mathrm{mg} / \mathrm{m}^{3}$ sebesar 75,83\% (Gambar 9). Pola distribusi spot tangkapan ikan berubah setiap bulan terutama di musim tangkap akibat adanya kenaikan massa air di Laut Banda, distribusi densitas klorofil-a yang tinggi berada disekitar pesisir pulau (Gambar 10).

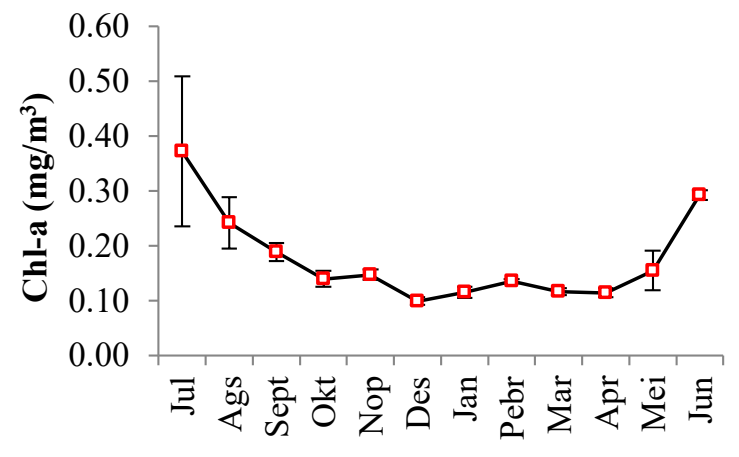

Gambar 8. Rata-rata Densitas Klorfil-a Pada Areal penangkapan Laut Banda

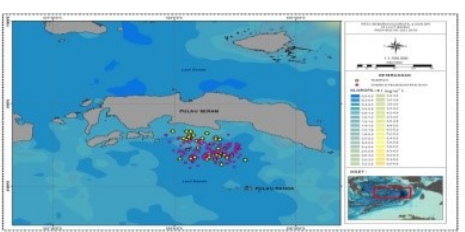

Juli

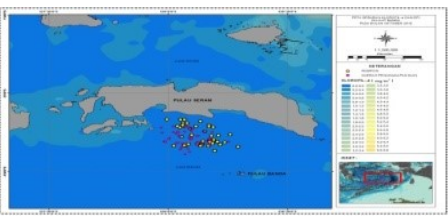

Oktober

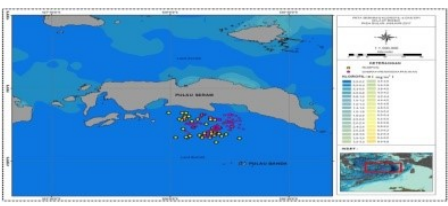

Januari

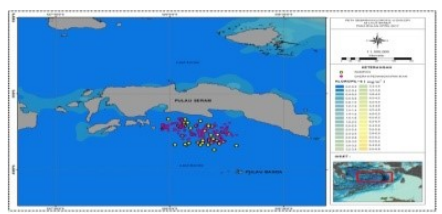

April

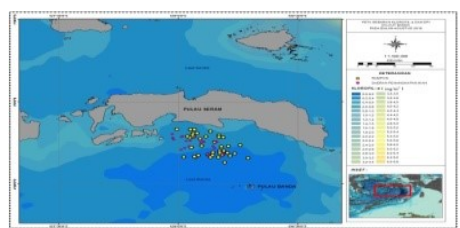

Agustus

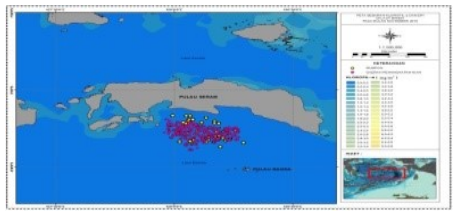

Nopember

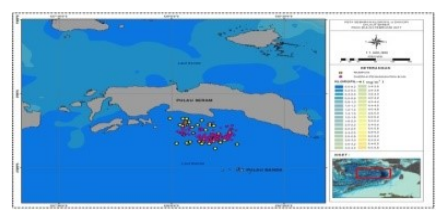

Pebruari

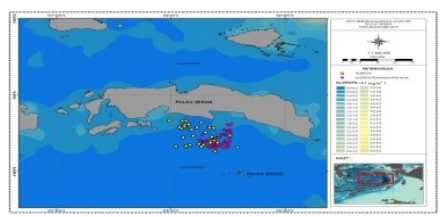

Mei

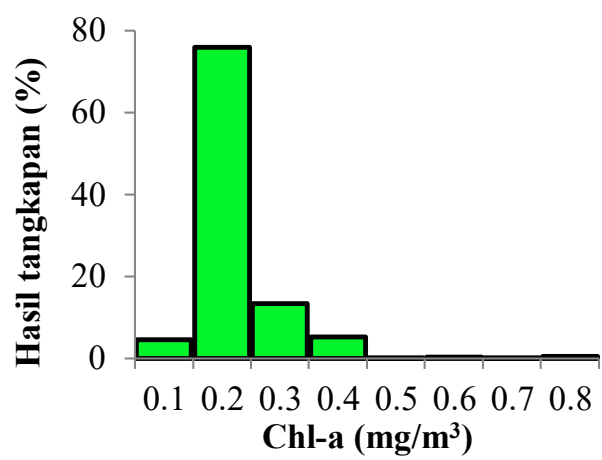

Gambar 9. Presentase Hasil Tangkapan Pada Klorofil-a Pada Areal Penangkapan Laut Banda

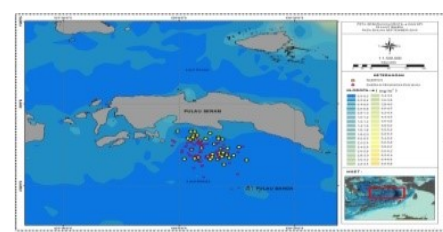

September

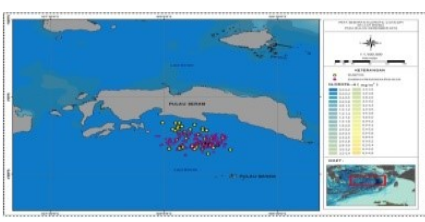

Desember

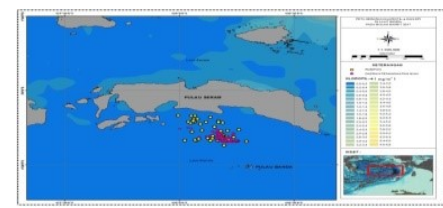

Maret

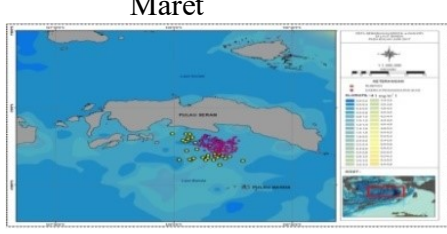

Juni

Gambar 10. Peta Distribusi Daerah Penangkapan Ikan Tuna Madidihang hubungannya dengan Klorofil-a Di Laut Banda

Berdasarkan hasil penelitian ini bahwa densitas klorofil-a sebagai karakteristik penangkapan ikan tuna madidihang berada di kisaran $0,2-0,4 \mathrm{mg} / \mathrm{m}^{3}$. Distribusi dan kelimpahan ikan pelagis besar berada pada densitas klorofil-a sekitar $0,20-0,30 \mathrm{mg} / \mathrm{m}^{3}$ 
dan teronsentrasi pada isodept klorofil-a $0.2 \mathrm{mg} / \mathrm{m}^{3}$ (Zainuddin, et al, 2013; Safruddin dkk., 2014). Keberadaan konsentrasi klorofil-a $\geq 0.2 \mathrm{mg} / \mathrm{m}^{3}$ mengindikasikan keberadaan plankton yang cukup untuk menjaga kelangsungan hidup ikan ekonomis penting.

Trend rata-rata kenaikan SPL di Laut Banda secara simultan terjadi pada bulan Juli - Nopember yang diikuti oleh menurunnya densitas klorofil-a, kondisi ini sebagai indikasi telah terjadi fenomena up-welling. Fenomena up-welling terjadi pada bulan Juni - Agustus (Musim Timur) karena bertiupnya angin Muson Tenggara yang membawa massa udara dingin dari daratan Australia dengan perubahan sebesar $4{ }^{\circ} \mathrm{C}$, fenomena ini diikuti peningkatan klorofil-a dan produktivitas perairan (Gordon dan Soesanto, 2001; Tubalawony dkk, 2016; dan Tapilatu Yosmina, 2016).

\section{Hubungan Parameter Oseanografi dengan Hasil Tangkapan}

Hasil analisis Generalized Additive Models (GAMs) menunjukkan bahwa parameter Suhu Permukaan Laut dan densitas klorofil-a secara bersama-sama berpengaruh sangat nyata terhadap hasil tangkapan dengan nilai kontribusi 25,2\% (Tabel 1). Kontribusi parameter lain diduga turut berpengaruh yaitu: faktor perubahan cuaca seperti kecepatan angin, kecepatan arus, tinggi gelombang, curah hujan, dan faktor-faktor produksi seperti penggunaan umpan, kapasitas armada, dan metode penangkapan.

Tabel 1. Hasil analisis parameter oseanografi dengan metode GAMs

\begin{tabular}{|c|c|c|c|c|}
\hline Model & Variabel & p-value & CDE (\%) & Sampel (n) \\
\hline \multicolumn{5}{|c|}{ LAUT BANDA } \\
\hline \multirow{3}{*}{ SPL + Klorofil-a } & $\operatorname{SPL}\left(\mathrm{X}_{1}\right)$ & $2.33 \mathrm{e}-08 * * *$ & \multirow{3}{*}{25,2} & \multirow{3}{*}{1.948} \\
\hline & Chl-a $\left(X_{2}\right)$ & $2 \mathrm{e}-16 * * *$ & & \\
\hline & Chl-a (X2) & $9.98 \mathrm{e}-06 * * *$ & & \\
\hline
\end{tabular}

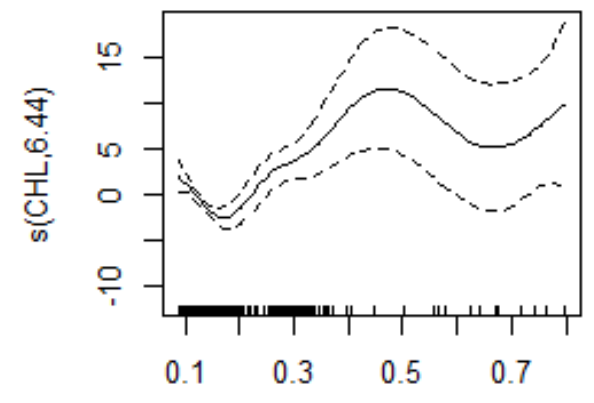

$\mathrm{CHL}$

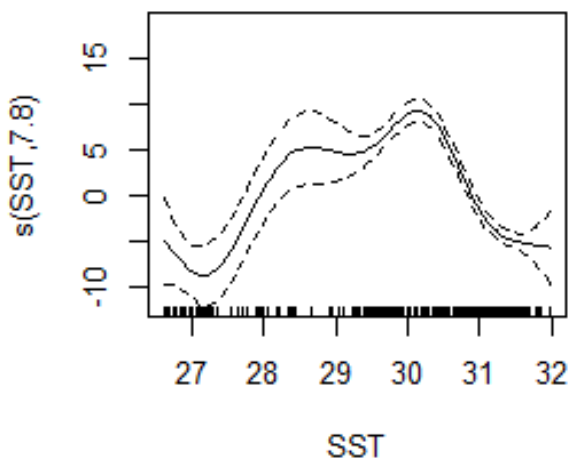

Gambar 10. Kondisi oseanografi optimum tuna madidihang dengan metode GAMs

Kondisi optimum ikan tuna madidihang kaitannya dengan distribusi dan kelimpahannya berpengaruh positif masing-masing untuk parameter Suhu Permukaan Laut sebesar $30^{\circ} \mathrm{C}-30,5^{\circ} \mathrm{C}$ dan Klorofil-a sebesar $0,1-0,2 \mathrm{mg} / \mathrm{m}^{3}$ (Gambar 11). Kondisi parameter optimal (SPL dan Klorofil-a) jenis tuna seperti di perairan Provinsi Aceh berkisar antara 26.19- $32.8{ }^{\circ} \mathrm{C}$ dan klorofil-a 0.02- $3.47 \mathrm{mg} / \mathrm{m} 3$ (Bahri dkk, 2017), di perairan Teluk Bone antara $29-29,5^{\circ} \mathrm{C}$ dan konsentrasi klorofil- $a$ 0,2-0,4 mg/m (Safruddin dkk, 2018). Tetapi kisaran suhu yang disukai oleh ikan cakalang dan ikan madidihang $18^{\circ} \mathrm{C}-31^{\circ} \mathrm{C}(\mathrm{FAO}, 2003)$. Adanya variasi parameter oseanografi kaitannya 
dengan musim, perubahan iklim, kondisi termoklin, dan perubahan lintang (Nguyen\&Doan, 2014).

\section{KESIMPULAN}

Kesimpulan dari hasil penelitian adalah :

1. Kontribusi jenis madidihang (Thunnus albacares) sebesar 59,96\% dari total produksi komoditas tuna (non cakalang) di Maluku 24.259,2 ton, CPUE rata-rata pancing ulur $1.011,73 \mathrm{~kg} /$ bulan, dan musim penangkapan bulan Januari-April dan Oktober-Desember.

2. Parameter Suhu permukaan laut dan kloorofil-a berpengaruh positif terhadap distribusi dan kelimpahan tuna madidihang di Laut Banda dengan kondisi optimum $30^{\circ} \mathrm{C}-30,5^{\circ} \mathrm{C}$ dan $0,1-0,2 \mathrm{mg} / \mathrm{m}^{3}$.

\section{DAFTAR PUSTAKA}

Bahri S, Simbolon D, Mustaruddin, 2017. Analisis Daerah Penangkapan Ikan Madidihang (Thunnus albacares) Berdasarkan Suhu Permukaan Laut Dan Sebaran Klorofil-a Di Perairan Provinsi Aceh. Jurnal Teknologi Perikanan dan Kelautan Vol. 8 No. 1 Mei 2017: 95-104.

Bailey M, Jimely Flores, Sylvester Pokajam, U. Rashid Sumaila, 2012. Towards better management of Coral Triangle tuna. Ocean \& Coastal Management. Elseiver.

Cabral R, Trinidad A.C, Geronimo R, and Alin P, 2012. Opportunities and Challenges in the Coral Triangle. Enviromental Science and Technology. American Chemical Society.

Gordon A.L dan Susanto R.D, 2001. Banda Sea Surface-Layer Divergence.Ocean Dinamics. Springer-Verlag 2001.

Haruna, Mallawa A., Musbir, Zainuddin M., 2018 Population dynamic indicator of the yellowfin tuna Thunnus albacares and its stock condition in the Banda Sea, Indonesia. AACL Bioflux 11(4):1323-1333.

Jufri M, Amran A, dan Zainuddin M, 2014. Karakteristik Daerah Penangkapan Ikan Cakalang Pada Musim Barat Di Perairan Teluk Bone. Jurnal IPTEKS PSP, Vol. 1 (1) April 2014: 1 - 10 ISSN: 2355-7298.

Kekenusa, J.S. 2006. Analisis penentuan musim penangkapan ikan cakalang (Katsuwonus pelamis) di perairan sekitar Bitung Sulawesi Utara. Jurnal Protein 13(1): 103-109.

Nguyen D.T and Doan V. B, 2014. Using Remote Sensing Data for Yellowfin Tuna Fishing Ground Forecasting in Vietnamese Offshore Areas. International Journal of Emerging Technology and Advanced Engineering Website: www.ijetae.com (ISSN 2250-2459, ISO 9001:2008 Certified Journal, Volume 4, Issue 2, February 2014).

Nurdin E, Sondita MFA, Yusfiandayani R, Baskor M, 2015. Produktivitas dan Musim Penangkapan Ikan Madidihang (Thunnus albacares bonnaterre, 1788) Pada perikanan Skala Kecil Di Pelabuhan Ratu, Jawa Barat. J. Lit. Perikanan Indonesia. Vol. 21. No 3 September 2015: 147-154.

Safruddin, M. Zainuddin, Chair Rani. 2014. Prediksi Daerah Potensial Penangkapan Ikan Pelagis Besar Di Perairan Kabupaten Mamuju. Jurnal IPTEKS Pemanfaatan Sumberdaya Perikanan. Vol.1 (2): 185 -195. ISSN: 2355-729X. 
Safruddin, Yashinta Kumala Dewi, Rachmat Hidayat, M.T Umar, Zainuddin Mukti, 2018. Studi Kondisi Oseanografi pada Daerah Penangkapan Ikan Pelagis Besar dengan Menggunakan Pole and Line di Perairan Teluk Bone. Prosiding Simposium Nasional Kelautan dan Perikanan, V. Universitas Hasanuddin, Makassar, 5 Mei 2018.

Setiawan U, Wenno J, Kayadoe, M.E, 2016. Laju tangkap dan musim penangkapan madidihang (Thunnus albacares) dengan tuna hand line yang didaratkan di Pelabuhan Perikanan Samudera Bitung. Jurnal Ilmu dan Teknologi Perikanan Tangkap 2(4): 147-154, Desember 2016 ISSN 2337-4306.

Simbolon D, 2011. Bioekologi dan Dinamika Daerah Penangkapan Ikan. Departemen Pemnfaatan Sumberdaya Perikanan Fakultas Perikanan dan Ilmu Kelautan, IPB. Bogor

Tawari R.H.S, Simbolon D, Haruna, 2019. Productivity of Small-Scale Yellowfin Tuna Fishing in West Region of Ceram District, Moluccas Province, Indonesia. International Journal of Environment, Agriculture and Biotechnology (IJEAB) Vol-4, Issue-5, Sep-Oct- 2019 https://dx.doi.org/10.22161/ijeab.45.25 ISSN: 2456-1878

Tapilatu Yosmina, 2016. Keragaan Oseanografi Biologi Di Laut Banda. Pembangunan Kelautan Dan Perikanan Berbasis Laut Banda. IPB Press. ISBN: 978-602-440021-7.

Tubalawony Simon, Purnama Ray dan Ferdinandus Jovren 2016. Penentuan Daerah Potensial Upwelling dan Kaitannya Dengan Pengelolaan Laut Banda. Pembangunan Kelautan Dan Perikanan Berbasis Laut Banda. IPB Press. ISBN: 978-602-440-021-7.

Zainuddin M, Nelwan A.F, Farhum A., Hajar M.A.I, Najamuddin, Kurnia M, and Sudirman. 2013. Characterizing Potential Fishing Zone of Skipjack Tuna during the Southeast Monsoon in the Bone Bay-Flores Sea Using Remotely Sensed Oceanographic Data. International Journal of Geosciences, Vol. (4): 259-266. http://dx.doi.org/10.4236/ijg.2013.41A023.

Zainuddin M, Safruddin, Selamat M.B, Mallawa A, 2015. Karakterisasi Habitat Ikan Cakalang di Teluk Bone dan Laut Flores Pada Musim Barat Menggunakan Data Satelit dan Teknik Sistem Informasi Geografis: Sebuah Pengantar Menuju Pengembangan Sistem Informasi Perikanan. Prosiding Simposium Nasional Kelautan dan Perikanan II Makassar. Fakultas Ilmu Kelautan dan Perikanan Universitas Hasanuddin, ISBN: 978-602-71759-1-4. Hal 367-371.

Zainuddin M, M I Amir, A Bone, S.A Fahrum, R Hidayat, A.R.S Putri, A Mallawa, Safruddin, and M Ridwan, 2019. Mapping distribution patterns of skipjack tuna during January-May in the Makassar Strait. The 2nd International Symposium on Marine Science and Fisheries (ISMF2) - 2019. IOP Conf. Series: Earth and Environmental Science 370 (2019) 012004. doi:10.1088/1755-1315/370/1/012004 